\title{
Psalms en hulle Sitz(e) im Leben. 'n Analise aan die hand van Psalm 55 en 74
}

D J Human

\section{ABSTRACT}

Psalms and their Sitz(e) im Leben. An analysis in view of Psalms 55 and 74

It is hermeneutically unthinkable to expose any Old Testament text, without taking its historic and/or cultic Sitz im Leben into consideration. This especially applies for the texts of the psalms. But, vague formulations and generalised language, though, make this effort in the psalms extremely difficult. In view of the eclectic chosen examples of Psalms 55 and 74, this article shows how several Sitz(e) im Leben are identified by exegetes for the understanding of a psalm. More than one historical situation could have instigated the origin and content of a psalm. To determine the socalled "original" Sitz of psalms, is therefore almost impossible. But, this state of affairs should not cause the exegete or preacher to be sinical about exegetical method or diachronic research of psalm texts. Various identified Sitz(e) behind the text should create a common dealer - an athmosphere or interpretation-direction - which create a freedom in the exegete or reader's mind to identify suitable situations for the reinterpretation or actualisation of a psalm. In this regard, a literary or textimmanent reading is not complete without diachronic exegesis. Despite uncertainty about the so-called "original" Sitz im Leben behind most psalms, exegetes should be more than enthusiastic to struggle with the search for a historic or cultic Sitz(e) behind the text. This will add value to the understanding of every psalm.

\section{INLEIDING}

'n Teks sonder sy Sitz im Leben is ondenkbaar. Daarby is 'n onderskeid tussen die historiese en kultiese Sitze im Leben van enige Bybelteks noodsaaklik. Waar eersgenoemde Sitz na die historiese ontstaan en situasie(s) agter die teks vra, bekyk laasgenoemde 'n teks se kultiese gesitueerdheid en funksionering. Dit is buitendien een van die belangrikste hermeneutiese sleutels om die betekenis van enige Bybelse teks teen sy historiese agtergrond te verstaan. Die konteks of kontekste waarin 'n teks ontstaan het, so word gesê, moet ons help om tot die betekenisvolle 
ontginning van die teks te kom. Hierdie uitgangspunt klink eksegeties natuurlik baie ortodoks en selfs vroom, maar is makliker gesê as gedoen.

Om hierdie hermeneutiese reël op tekste van die psalms toe te pas, is moeilik. Die psalms en selfs talle ander Ou-Testamentiese tekste laat hulle nie enkelvoudig teen die agtergrond van een konteks verstaan nie. Dit is feitlik onmoonlik om by die psalms die sogenaamde "oorspronklike" historiese konteks van die teks te rekonstrueer. Die rede daarvoor is die komplekse wordingsgeskiedenis van elke teks. Die meeste Ou-Testamentiese tekste het hulle oorsprong in 'n mondelinge tradisie, wat deur die moderne eksegeet nouliks nagespeur kan word. Vae historiese beskrywings en uiters veralgemeende taal- en uitdrukkingsformules dra verder tot hierdie probleem by.

Wanneer die sogenaamde "oorspronklike" historiese konteks agter 'n psalm nie bepaal kan word nie, beteken dit nie dat so 'n teks betekenisloos bly of konteksloos en fundamentalisties gelees moet word nie. Die eksegeet of prediker moet verder nie ontmoedig word om historiese of kultiese kontekste vir sy teks te soek nie. Allermins moet daar in 'n teksimmanente monisme verval word deur die teks slegs sinkronies te ontleed en te verstaan. In taal is daar ook historiese spatsels wat rigtingduiders vir 'n teks se verstaan kan oplewer. Daarom moet historiese of diakroniese teksanalise nie teenoor die literêre-teksimmanente of sinkroniese lees van 'n teks staan nie. Om betekenis aan die teks te gee, moet beide benaderings aanvullend tot mekaar funksioneer. Sowel teksimmanent- as histories georiënteerde eksegete mag mekaar nie van subjektiewe inlees van navorsingsresultate beskuldig, asof elkeen die monopolie op die teks se verstaan het nie. Beide het voorveronderstellings en beperkings. Daarom moet elkeen die teks nederig en aanvullend tot mekaar se navorsingsresultate uitlê. Dit geld in besonder vir die psalms.

Die doel van hierdie artikel is om aan te toon hoe moeilik dit is om die presiese historiese en kultiese Sitz(e) im Leben van 'n psalm vas te stel. Die verskeidenheid van kontekste waarteen een psalm verstaan kan word, moet egter nie tot 'n gebrek aan en onverskilligheid teenoor diakroniese eksegese van psalms aanleiding gee nie. Die gemene deler in die verskeie kontekste waarteen 'n psalm verstaan kan word, moet aan die eksegeet en prediker die vryheid gee om soortgelyke kontekste uit sy eie wêreld te identifiseer, waarin die psalm vir die moderne mens weer nuwe betekenis kry. So word die psalm in moderne kontekste weer herinterpreteer en 'n antieke Godservaring weer herbeleef. Vir hierdie doel word 'n individuele en volksklaaglied, naamlik Psalms 55 en 74 eklekties analiseer. 'n Vertaling van elke psalm word gemaak sodat die leser argumente makliker 
kan volg. Die hebreeuse teks van elkeen moet egter byderhand gehou word.

\section{$2 \quad$ PSALM 55}

\subsection{Vertaling}

“1 Vir die musiekleier. Met snarespel. 'n Onderwysing van Dawid.

2 Hoor, o God, my gebed en moet $U$ nie van my smeking verberg nie;

3 luister aandagtig na my en antwoord my; ek is deurmekaar in my gesug en ek steunkla

4 vanweë die roepstem van die vyand en die onderdrukking van die goddelose, want hulle stort onreg op my af en met toorn staan hulle my teen.

$5 \mathrm{My}$ hart is beangs in my binneste en verskrikkinge van die dood het my oorval.

6 Vrees en bewing kom oor my en angs oorweldig my.

7 Toe het ek gedink: 'Ag, as ek maar vlerke gehad het soos 'n duif, dan sou ek wegvlieg en (êrens) 'n woonplek gaan maak;

$8 \mathrm{Kyk}$, ek sou ver wegvlug; ek sou in die woestyn gaan oornag. Sela.

9 Ek sou haastig vir my 'n skuilplek teen dié kragtige wind, die stormwind gaan soek.

10 Verwar hulle, o Heer, maak hulle taal (vir mekaar) onverstaanbaar, want ek het geweld en stryd in die stad gesien.

11 Bedags en snags het hulle al rondom (haar = die stad) op haar stadsmure gemaal, met onreg en geweld in haar midde,

12 verderf in haar binneste; ja, verdrukking en bedrog het nie van haar stadspleine af gewyk nie,

13 want dit is nie die vyand wat my smaad aandoen nie, anders sou ek dit verdra; dit is nie iemand wat my haat, wat hom grootdoenerig teenoor my hou nie, anders sou ek my vir hom verberg;

14 Maar dit is jy, 'n man soos ek, my vriend en my vertroueling.

15 Dit is ons wat mekaar se vertroulikheid in die huis van God geniet het, terwyl ons in die (tempel-)gedruis gewandel het.

$16 \mathrm{Mag}$ die dood hulle oorval; mag hulle lewendig in die doderyk neerdaal, want daar is booshede in hulle blyplek, in hulle midde. 
$17 \mathrm{Ek}$, tot God sal ek roep en die Here sal my verlos.

18 Saans en soggens en smiddae sug en steun ek, maar Hy sal na my stem luister.

19 Hy red my (lewe) heilvol van die stryd teen my, want hulle is baie teen my.

20 God sal hoor en hulle antwoord, ja, Hy wat van die oertyd af heerskappy voer. Sela.

By hulle is daar geen verandering nie en hulle vrees God nie.

$21 \mathrm{Hy}$ het sy hande teen sy seënbedes uitgesteek; hy het sy verbond ontheilig.

22 Die botterwoorde van sy mond was glad en sy hart is stryd; sy woorde is sagter as olie, maar hulle is getrokke swaarde.

23 Werp (jouself) op die Here, Hy sal vir jou gee, Hy sal jou versorg; Hy sal die regverdige nie vir altyd laat wankel nie.

24 Maar U, o God, U laat hulle neerdaal in die put van verderf; dié moordenaars en bedrieërs sal nie die helfde van hulle leeftyd sien nie. Maar ek, ek sal op U vertrou."

\subsection{Historiese Sitz im Leben}

Die vae formulerings en gebrek aan konkrete beskrywings in Psalm 55 maak die identifisering van spesifieke historiese gebeure agter die teks feitlik onmoontlik' ${ }^{1}$. Dit bemoeilik die bepaling van 'n historiese Sitz en laat die vraag ontstaan of die digter nie 'n doelbewuste algemene en vaag geformuleerde situasie wil skilder om met digterlike intensies 'n bepaalde teologiese oordrag te bewerkstellig nie. Sou dit waar wees, is die literêre interpretasie van die teks onafwendbaar. Dan word dit belangrik om na die funksie van en polariteit tussen historiese beelde, beskrywings en gebeure te vra.

'n Literêre verstaan van Psalm 55 isoleer hom nie van die geskiedenis nie. Dit beteken slegs dat historiese gebeure, feite en motiewe op 'n literêre wyse aangewend word ten einde 'n bepaalde geloofsgetuienis te kommunikeer. Die digter wend feite en motiewe dus nie aan om 'n spesifieke historiese gebeurtenis te rekonstrueer nie. Die literêre funksie dra tot die teologiese intensie by.

Die historiese identifisering van die "ek" en sy stryd met 'n ontroue vriend (13-15), die tipering van die onrussituasie in die stad $(10-12,16)^{2}$ asook die identiteit van die vyand lewer vir eksegete motiverende argumente om 'n datering van die psalmteks voor te stel.

Om sowel 'n outeur ${ }^{3}$ as 'n datum ${ }^{4}$ vir Psalm 55 aan te wys, bly weens 'n gebrek aan konkrete gegewens 'n moeilik of onmoontlike taak. 
Die situasie in die stad kan histories nie vasgepen word nie. Binne sy literêre konsep wil die stad-motief eerder ruimtelikheid tot uitdrukking bring waarbinne verskeie gepersonifieerde 5 onregsmagte funksioneer. Gevolglik is die leërmag en militêre situasie wat Goulder ${ }^{6}$ op grond van die vyand se vervolging (3), die doodsgevaar (4) en ontvlugting (6 ev) identifiseer, onaanvaarbaar en onoortuigend.

Die historiese bepaling van die vyand in die psalms het tot heelwat diskussie, spekulasie en meningsverskil aanleiding gegee ${ }^{7}$. Die gesprek daaroor is nog lank nie voltooi nie. Dit blyk egter belangriker te wees om die vraag na die literêre funksie wat die vyand vervul, te beantwoord. Die gesiglose vyand druk literêr 'n mag uit wat in 'n bepaalde polariteitsverhouding tot die regverdige en/of tot God staan. Binne die spanning van hierdie polariteit kom die teologiese inhoud(e) uit die psalm na vore.

\subsubsection{Verskillende moontlikhede}

Verskeie pogings is al aangewend om deur die historiese identifisering van sowel die vyand as die ontroue vriend die psalm binne 'n bepaalde tydgleuf te plaas. Dateringsvoorstelle lê wyd tussen die tydperke van Saul se koningskap (+1030 vC) en die Makkabeërs (+165 nC) verspreid en sluit die volgende moontlikhede in:

- Dat koning Saul die ontroue vriend is, word selfs nie eers deur diegene wat die voorstel suggereer ${ }^{8}$ as eerste moontlikheid aangebied nie. Die vraag is net: Was die bedreigde persoon Dawid en hoe sal die meervoud van vyande $(4,19)$ dan verklaar word? Motivering vir hierdie voorstel is nie oortuigend nie.

- Verskeie eksegete verklaar die psalm vanuit 'n Dawidiese situasie. Op grond van die opskrif לדור word Dawid as outeur en noodlydende geïdentifiseer met Agitofel wat vir Absalom bystaan ( 2 Sam $15 \mathrm{ev}$ ), as sy verraaier en ontroue vriend 9 .

Daar is verskeie argumente teen hierdie voorstel. Die opskrif is eerstens nie 'n sleutel tot die historiese interpretasie van 'n teks nie, maar dit gee 'n literêre realiteit weer ${ }^{10}$. Ander vername besware ${ }^{11}$ kan met die volgende vrae verwoord word: Was Agitofel van gelyke stand (כערכי) met Dawid? Sou Dawid die onreg en korrupsie van sy eie regering bekla of beskryf? 'n Positiewe antwoord hierop kan nie met oortuiging gegee word nie. Voorts was Absalom se sameswering uit Hebron (2 Sam 15:9) en nie uit Jerusalem gerig nie. Dawid het ook nie probleme gehad om 
te ontvlug soos verse 7-9 kan suggereer nie (2 Sam 15:14).

Saam met Seidel ${ }^{12}$ kan kritiek op Goulder uitgespreek word dat die psalm an sich geen oortuigende rede(s) bevat "für die Zuordnung dieser Psalmen (bedoelende 51-72) zu einem Prozessionsgeschehen" nie.

- Die voorstel word verder gemaak dat die psalm die geloofsgetuienis van 'n Judese koning 13 is. Die vraag is egter: Sou die psalm dalk partytwiste onder Manasse ${ }^{14}$ reflekteer of was daar verraad onder troepe teen Hiskia (Jes 36:2,14)? ${ }^{15}$ Selfs die regeertyd van Jojakim (597) sou volgens hierdie standpunt in aanmerking geneem kon word, indien die boek Habakuk ${ }^{16}$ die onreg uit hierdie tyd beskryf.

Alhoewel 'n hele aantal psalmnavorsers die "ek" in die psalms met 'n koning identifiseer, bly die voorstel te vaag om daarmee 'n spesifieke historiese Sitz im Leben vir Psalm 55 vas te pen. Die feit dat verskillende moontlikhede in so 'n voorstel geakkommodeer kan word, bevestig die vaagheid daarvan.

- Omdat die psalm illustrasies van die profetiese literatuur weerspieël, is dit veral ooreenkomste met Jeremia 9 en 20 wat eksegete ${ }^{17}$ laat vermoed dat die profeet Jeremia die bidder/digter is met Pasgur as sy verraaier en ontroue vriend.

Hierdie standpunt is nie waterdig nie aangesien Pasgur nêrens as 'n intieme vriend van Jeremia aangedui word nie. As priester was hy waarskynlik ook nie van dieselfde stand (14) as die profeet Jeremia nie ${ }^{18}$.

- Briggs \& Briggs ${ }^{19}$ is op grond van die beskrywing van mure en stadspleine $(11,12,16)$ daarvan oortuig dat Psalm 55 nie vóór Nehemia se tyd gedateer kan word nie. Daarom situeer hy die psalm in die tyd van Nehemia toe daar nie buitelandse gevaar was nie, maar wel onrus en geweld in die stad Jerusalem.

- Buttenwieser 20 beskou Psalm 55A (1-12, 17-20, 23) as 'n historiese bron vir Ptolemeus se besetting van Jerusalem tussen 318 en 312 vC. Die stad is in dié tyd drie maal beleër en die psalm is volgens hom nie later as 312 vC. geskryf nie. Buttenwieser se motivering en datering is slegs op 'n deel van Psalm 55 gebaseer terwyl hy die res as ' $n$ fragment tipeer en ongedateerd laat. Sy voorstel is dus onbevredigend. 
- Die plasing van die psalm in die Makkabeërtyd geniet prominente aandag onder navorsers. Duhm ${ }^{21}$ meen dat die digter een van die Chasidim was, terwyl sy ampsgenoot en teëstander die priester of tempelbeampte Alkimos was wat onreg en verraad gepleeg het (1 Makk 7:12-18; 9:54). Kittel22 wys ook op "Parteikämpfe" in die laat geskiedenis van Palestina en identifiseer die digter as die hoëpriester Onias 3 wat tydens die regerings van Seleukus IV $(+187-175)$ en Antiochus IV Epiphanus onderdruk is. Sy valse vriend is dan Alkimos (1 Makk 7:9-25) of Simon (2 Makk 3:4). Treves ${ }^{23}$ wat hierby aansluit, wys op die Griekse invloed van vers 7 en beskryf die psalm as 'n "allusion" van die gebeure rondom 168 vC (1 Makk 1:38; 2 Makk 4:40-42). Sy voorstel is dat die hoëpriester Onias deur Simon of Menelaus (1 Makk 4:1-38) verraai is.

Alhoewel die Makkabeërtyd 'n voortreflike historiese plasing van die teks mag wees, bly dit 'n vermoede wat nie die enigste oortuigende moontlikheid is nie. Daarom bied enkele eksegete ${ }^{24}$ dit as één van die dateringsmoontlikhede aan sonder om 'n bepaalde keuse vir 'n spesifieke Sitz im Leben te maak.

- Ander perspektiewe op die identiteit van die outeur of bidder word ook gegee: Op voetspoor van Mowinckel meen Gunkel25 "der Verfasser befindet sich in der Diaspora." Hy bied die voorstel egter net vir een van sy twee geïdentifiseerde gedigte aan, naamlik vir $19 c-22$ en 24 . Die gevolg is dat die datering en identiteit van die outeur van die psalm as geheel in die lug hang.

Dat die bidder "ein Führer" of koning is ${ }^{26}$, is moeilik vanuit die teks bewysbaar. Eksegeties sou dit meer verantwoordbaar wees om die "ek" as verteenwoordiger van sy gemeenskap te beskryf. Derhalwe is die begrip $70 \pi^{27}$ van Duhm en Kraus, histories gesproke, 'n beter voorstel.

Hierdie stortvloed van moontlikhede bevestig die onsekerheid asook die onmoontlikheid om 'n presiese historiese Sitz im Leben te identifiseer. Dit dra tot die vermoede by dat die psalm 'n doelbewuste algemeen en vaag geformuleerde situasie skilder. Daarmee is sy wortels nie uit die geskiedenis uitgetrek nie, maar die digter wend historiese gegewens op so 'n wyse aan dat mense uit verskeie soortgelyke kontekste met die inhoud daarvan kan identifiseer.

Die literêre verstaan van die psalm vereis nie dat die teks teen slegs een spesifieke historiese situasie interpreteer moet word nie. Daarvoor 
lewer die motief van byvoorbeeld die ontroue vriend, wydverbreid in die boeke van Job, Psalms, Spreuke, Miga en ander tekste, afdoende bewys. Die identifisering van die ontroue vriend met Agitofel, Pasgur, Simon, Menelaus, Alkimos en ander, is legitiem en word 'n hermeneutiese sleutel sodat Jan Alleman hom in die twintigste eeu met die teks in 'n soortgelyke situasie kan identifiseer.

Ten spyte van die eksegeet se stameling om 'n historiese Sitz im Leben vas te pen, skemer enkele oortuigende argumente deur ten einde die teks aan 'n laat ná-eksiliese tydperk toe te ken. Verskeie navorsers ${ }^{28}$ bevestig op grond van taalkundige en stilistiese redes 'n ná-eksiliese datering. Motiverings vir 'n laat ná-eksiliese datum behels:

- Die vermoedelik Arameïsmes of Aramese invloede (יהבק ; ..23) op Psalm 55.

- Priesterlike invloede wat in die verbinding van "berit" met sowel חלל na vore tree. "Berit" se verbintenis met beide begrippe is besonder in eksiliese of ná-eksiliese tekste opvallend ${ }^{29}$. Daarbenewens dra die sterk priesterlike bewerking van en invloed op die psalm in sy geheel tot die gevolgtrekking by dat die Endgestalt waarskynlik deur 'n laat ná-eksiliese hand bewerk is.

- Die traditionsgeschichtliche verbande met die boek Daniël dui ook op 'n ná-eksiliese datering. Daniël 6:11 se weerspieëling van die gebedstye uit die ná-eksiliese Jodendom ${ }^{30}$, wat waarskynlik in (18) neerslag vind, dui óf op 'n afhanklikheid van die Daniëlboek - wat onwaarskynliker is - of op 'n beïnvloeding van die tydsgees en omstandighede op beide tekste. Dit bevestig die vermoede van 'n laat datering.

Die finale teks van Psalm 55 sou dus met hierdie motivering aan 'n laat náeksiliese tydperk toegeken kon word.

\subsection{Kultiese Sitz im Leben}

Die psalm se verband met die kultus kan sowel literêr as inhoudelik aangetoon word. Dit is duidelik dat Psalm 55 teen die agtergrond van 'n bepaalde kultiese Sitz im Leben gefunksioneer het. Om die verstaan van die psalm egter uitsluitlik van die kultus afhanklik te maak, sou 'n eensydige interpretasiesleutel wees. Die psalm is waarskynlik ook by ander gebeds- of meditasiegeleenthede aangewend. 
Goulder ${ }^{31}$ plaas die teks binne die raamwerk van 'n kultgeschichtlichehistorisierende interpretasie van Psalms 51-72. Volgens hom vorm die psalm deel van 'n kultiese opvoering en resitering van Dawidiese gebede. Dit handel oor die troonopvolgingsgeskiedenis wat strek vanaf Uria se dood tot in Salomo se tyd. Hierdie tese is uiters vindingryk. Die opskrif לדוד saam met die inhoud word egter te gedwonge aan Dawid en sy leeftyd verbind, sodat ook hierdie tese nie die enigste interpretasiesleutel van die psalm is nie.

Die teks bevat verskillende duiders om sy kultiese band en funksionering te illustreer. Hiervan lewer die volgende bewys:

- Alhoewel die opskrif למנצח בנגינת onseker is, is die musikale elemente wat in בנגינת opgesluit lê genoeg rede om 'n verband met kultus-musisering te vermoed.

- Die gebedskarakter (2-3,17-18) en spreke met God veronderstel dat die "ek" sy versoeke, wense en klaaguitdrukkings in die tempel by die kultus aan God voorgelê het. Inhoudelik word die bidder se kultusaktiwiteite met die aanduiding בבית אלהים (15) bevestig.

- 'n Oorvloed van kulties-priesterlike tradisiemomente ${ }^{32}$ ruim alle twyfel uit die weg dat die "ek" en sy voormalige vriend (14-15) kultusgangers was wat hul godsdiensaktiwiteite by die heiligdom beoefen het.

Teen hierdie agtergrond word dit duidelik dat sowel historiese as kultiese gegewens as aanvulling tot die literêre ontsluiting van Psalm 55 bydra. Om die oorspronklike en presiese Sitz im Leben te bepaal, is feitlik onmoontlik. Alhoewel gegewens vaag en onseker is, skep die pogings om 'n historiese konteks agter die psalm vas te stel, 'n klimaat wat die vryheid bied om soortgelyke kontekste vir die moderne psalmleser te identifiseer. Hierbinne kan die herbelewenis van die psalm 'n nuwe Godservaring vir die gelowige word.

\section{PSALM 74}

\subsection{Vertaling}

“1 'n Onderwysing van Asaf.

Waarom, o God, het U ons vir altyd verwerp?; (waarom) ontbrand U toorn teen die skape van $u$ weide? 
2 Dink aan $u$ volk (lett: vergadering), (wat) $U$ van vroegtyd af (al) in besit geneem het; (wat) $U$ as stam van $U$ erfdeel verlos het; hierdie Sionsberg waarop $U$ kom woon het.

3 Lig u voetstappe op na die ewige puinhope; alles het die vyand in die heiligdom vernietig.

$4 \mathrm{U}$ teenstanders het binne-in u vergaderplek gebrul; hulle het hulle vaandels as teken (daar) opgerig.

5 Dit het gelyk soos mense (lett: iemand) wat byle in 'n digte woud bome omhoog hef.

6 En nou slaan hulle sy houtsneewerk gelyktydig met byl en hammer(s) stukkend.

7 Hulle het $\mathrm{u}$ heiligdom met vuur aan die brand gesteek; tot op die grond het hulle die woonplek van u Naam ontheilig.

8 Hulle het by hulleself gedink: Ons sal hulle tegelyktydig vernietig. Hulle het (toe) al die woonplekke van God in die land vernietig.

9 Ons (eie) kentekens het ons nie gesien nie; daar was nie meer 'n profeet nie, asook niemand onder ons wat geweet het hoe lank (dit) nog (gaan duur) nie.

10 Hoe lank nog, o God, gaan die teenstander smaad aanrig, (hoe lank) gaan die vyand $u$ Naam vir altyd verag?

11 Waarom steek $\mathrm{U} u$ hand terug, ja, $\mathrm{u}$ regterhand in $\mathrm{u}$ skoot terug? Verdelg (hulle)!

$12 \mathrm{Ja}$, God is my Koning van vroegtyd af; Hy bewerk redding in die land.

$13 \mathrm{U}$ het die see met $\mathrm{u}$ mag in twee gedeel; $\mathrm{U}$ het die koppe van die (see)monsters op die water flenters geslaan.

$14 \mathrm{U}$ het die koppe van Leviatan verpletter; $U$ het hulle as voedsel aan 'n volk (van) woestynbewoners gegee.

$15 \mathrm{U}$ het fontein en waterstroom oopgesplit; $\mathrm{U}$ het standhoudende riviere laat opdroog.

16 Aan $U$ behoort die dag; aan $U$ behoort ook die nag; $U$ het (die baan) van maan en son vasgestel.

$17 \mathrm{U}$ het al die grense van die aarde vasgestel; somer en winter, $U$ het hulle geboetseer.

18 Dink daaraan, die vyand het $U$ gesmaad Here; ja, 'n dwase volk het $u$ Naam verag. 
19 Moenie die lewe van u tortelduif aan wilde diere gee nie; die lewe van $u$ ellendige moet $U$ nie vir altyd vergeet nie.

20 Aanskou u verbond, want die donker plekke van die land is vol blyplekke van geweld.

21 Laat die geringe nie beskaamd omdraai nie; die arme en ellendige sal u Naam loof.

22 Staan op, o God, voer u regsaak; dink aan die smaad wat die dwase $U$ elke dag aangedoen het.

23 Moenie die geskreeu van u teenstanders vergeet nie - die geraas van u opstandeling wat voortdurend opgaan".

\subsection{Historiese Sitz im Leben}

Om die historiese gebeure wat tot die ontstaan van Psalm 74 aanleiding gegee het te bepaal, lewer vir eksegete hoofbrekens op ${ }^{33}$. Veral omdat die afloop van gebeure so algemeen geskilder word sodat meer as een historiese gebeurtenis daarmee geïdentifiseer kan word, is die interpretasieproses nog moeiliker.

Interpretasiemoontlikhede sentreer veral rondom twee belangrike datums in Israel se geskiedenis, naamlik 586/7 vC met Nebukadneser se tempelvernietiging en wegvoering van die volk na Babel asook 168-5 vC in die Makkabeërtyd met Antiochus IV Epiphanes se tempelontheiliging.

Redelik algemene konsensus bestaan om die psalm eksilies of selfs ná-eksilies te dateer ${ }^{34}$. Argumente daarvoor is te vinde in die vernietiging $(3 \mathrm{a} \beta)$, ontwyding (4) en verbranding (7a $\alpha)$ van die tempel, die verbranding van al die heiligdomme van God $(7 \mathrm{a} \beta)$, die afwesigheid van die profetiese stem (9), die vyandsbedreiging en hoon $(10,18,22)$ wat prominent in die ná-ballingskapstekste is, ${ }^{35}$ asook die verwerping en toorn van God (1) wat eerder in ná-eksiliese psalms gestalte vind ${ }^{36}$. Selfs ד ("die verdrukte" 21) herinner aan die ná-eksiliese tyd toe agtergeblewene Jode deur heidene en Kanaäniete verdruk is. ' $n$ Laaste voorbeeld is die beeld in vers $14 a \beta$, wat veral uit Joods-eksiliese oorleweringe bekend is ${ }^{37}$. Dit blyk dus dat veral die interpretasie van $4 a \beta-9$ eksegete laat kop krap vir 'n meer spesifieke datering.

Argumente wat eksegete ${ }^{38}$ aanvoer vir 'n datum rondom $168-5 \mathrm{vC}$ is die volgende:

- Die afwesigheid van 'n profeet (9) kan die beste in die Makkabeërtyd verklaar word (1 Makk 2:6; 4:38,46; 9:27; 2 Makk 5:16,21; 8:35); 
- Slegs tempelgeboue is verwoes (5-6) en tempelskatte is geneem (1 Makk 1:21,25; 1 Makk 4:38), terwyl 'n groot bloedbad in 586/7 plaasgevind het;

- Op voetspoor van Aquila \& Symmachus word (8) eerder met "sinagoges" as met "tempels" of "heiligdomme" vertaal 39 .

Daarteenoor bied ander eksegete hulle teenargumente aan om die datum rondom of ná 586/7 vC vas te lê:

- Die stem van die profeet was in hierdie tyd ook stil, want

* 586/7 het "het instituut van het cultische profetisme uitgeschakeld" 40 .

* rondom die gebeure van 586/7 is Jeremia gevange geneem en na Egipte weggevoer, terwyl Esegiël in Mesopotamië (Babilonië) was. Gevolglik was daar geen profeet om die volk te lei nie (Jer 43:5ev; Eseg 7:26; 12:22).

* as gevolg van die mislukking van die positiewe profesieë (Jer 28) het die profete in 'n geloofwaardigheidskrisis by die volk verkeer sodat die ware profete nie vertrou of gehoor is nie. Vers 9 sou hierdie vertrouenskrisis uitdruk ${ }^{41}$.

* daar was ook ander tye in die geskiedenis van Israel waarin die profeet se stem stil was (1 Sam 3:1 en Klgl 2:9).

- Die afbrand van die tempel vind tydens 586/7 plaas (2 Kon 25:9);

- Daar is geen sprake in die psalm van tempelwyding aan 'n ander godheid of die oprigting van 'n Zeus-altaar soos in 168 die geval was nie ${ }^{42}$;

- Die beeld van die houtkapper in vers 5 kan waarskynlik op Nebukadnesar van toepassing wees, aangesien hy bekend was vir hierdie rol vanweë sy ontbostingsprogram in die Libanon ${ }^{43}$. Die afkap van 'n woud as aanduiding van die vernietiging van 'n volk is in die Ou Testament bekend ${ }^{44}$;

- Dat (8) "sinagoges" sou wees, is onwaarskynlik, aangesien dit die psalm se ontstaansdatum in 'n heelwat later tyd sal verskuif as wat historiese spatsels in die teks dit toelaat. Indien 
vers 8 'n later byvoeging tot die psalm sou wees, sou hierdie betekenismoontlikheid wel oorweeg kon word;

- Klaagpsalms soos Psalms 74, 89:6, 77:15ev asook Jesaja 51:9, wat die Chaoskampf-motiewe bevat, behoort sonder uitsondering tot die ballingskapstydperk ${ }^{45}$;

- Laastens behoort Psalm 74 tot die sogenaamde Elohistiese versameling (42-83), wat moeilik uit of rondom die Makkabeërtyd dateer ${ }^{46}$.

Kan en moet die eksegeet nou 'n keuse maak? Die antwoord hierop is 'n besliste ontkenning, aangesien 'n definitiewe dateringskeuse nie moontlik is nie. Alhoewel argumente vir die ontstaansdatum rondom of ná 586/7 meer oortuig, bied die "Sowel-As-benadering" van Peterson ${ }^{47}$, Loretz ${ }^{48}$ en Scroggie ${ }^{49}$ 'n bevredigende verklaring vir die historiese ontwikkeling van die psalm asook die spanninge in die teks. Indien verse 4 en $8^{50}$ of 12-17 as deel van die Wirkungsgeschichte by 'n latere heraktualisering tot die teks toegevoeg is, verteenwoordig hierdie benadering eweneens 'n bevredigende standpunt.

Tog moet daar van 'n paar ander verklaringsmoontlikhede kennis geneem word. Dit sluit in:

- 'n Tydperk êrens tussen 550 en 520. Dit verteenwoordig 'n tyd van totale en langdurige vernietiging van die tempel in die laaste jare voor die heropbou ${ }^{51}$. Hier kan dit selfs wees dat $(1,3,10)$, (10) daarop kon dui dat die psalm "some fifteen or twenty years after the destruction of Jerusalem" 52 geskryf is, vanweë die noukeurige beskrywing van die tempelvernietiging (4-9) deur 'n moontlike ooggetuie.

- Die gebeure tydens die regering van Manasse (2 Kon 21:16 ev) $)^{53}$.

- Die tempelontheiliging in 359-338 deur Artaxerxes en Ochus ${ }^{54}$.

- 'n Tydperk tussen Nehemia en Alexander die Grote 55 .

- Die katastrofiese jaar $344 \mathrm{vC}$ met die afbrand van die poorte, die godsdiensvervolging en oprigting van 'n altaar vir Zeus deur die leërs van Orophernes ${ }^{56}$. 
Weiser ${ }^{57}$ vat die onsekerheid om die historiese gebeure agter die teks te dateer saam, wanneer hy sê: "behind the psalm is an event that took place during the period from the fifth to the second centuries BC, about which we almost know nothing". Die gevolgtrekking wat ons hieruit maak, is "Man wird für alle Möglichkeiten offen sein müssen" 58. Wat egter met sekerheid beweer kan word, is dat die psalm waarskynlik op 'n ná-eksiliese ontstaansdatum en funksionering aanspraak kan maak.

\section{GEVOLGTREKKING}

Uit hierdie analise van eklekties gekose klaagliedere, Psalm 55 en 74, sou die volgende sake opnuut beklemtoon kan word:

1 Om die sogenaamde "oorspronklike" Sitz im Leben van psalms na te speur, kan op 'n skaal van "baie moeilik" tot "onmoontlik" gekarteer word. Algemene taalformulerings en vae historiese beskrywings kan die gevolg van psalms se wordingsgeskiedenis wees, waarin die oorsponklike ontstaansituasie(s) vervaag het tydens die mondelinge fase van oorlewering of verder verskuil is agter herbewerkings en latere toevoegings van verdere groeifases. In die psalmnavorsing is dit bekend dat tekste gegroei het deurdat hulle in soortgelyke daaropvolgende historiese kontekste herinterpreteer en geaktualiseer is ${ }^{59}$. Vaagheid is egter ook eie aan die taal van poësie en kan selfs die doelbewuste teologiese intensie of strategie van die psalmdigters wees, sodat mense die beskrewe en beleefde Gods- en lewenservarings opnuut kon herbeleef.

2 Die probleem om nie altyd die presiese historiese of kultiese Sitz im Leben van 'n psalm te bepaal nie, moet eksegete en predikers nie tot 'n metode-sinisme of metode-monisme aanspoor nie. Diakroniese analise moet daardeur nie aan sinkroniese of teksimmanente eksegese ondergeskik gestel word nie. Daar is genoeg historiese spatsels in tekste om 'n interpretasie-rigting of atmosfeer te bepaal waarin spesifieke psalms weer herbeleef en geïnterpreteer kan word. 'n Psalm sal voldoende rigtingduiders hê, dat 'n klaagpsalm byvoorbeeld nie in 'n vreugde-situasie of ' $n$ loflied nie in rou-omstandighede tot uitdrukking moet kom nie. Die veelheid van historiese kontekste waarteen 'n psalm verstaan kan word, moet die moderne eksegeet aanspoor om op die uitkyk te wees vir soortgelyke Sitz(e) im Leben waarin hy/sy die teks kan laat herleef en herinterpreteer. Dan kan hy maar met 'n veelheid van moontlikhede en kontekste asook 'n relatiewe onsekerheid oor die presiese ontstaansituasie van 'n teks werk. 
Hy/sy kan moontlikhede weeg en oorweeg, speel en oorkies, sonder om deur een enkele moontlikheid aan bande gelê te word.

3 Dit is dus nie nodig dat dié sogenaamde "oorspronklike" Sitz im Leben van 'n psalm vasgestel moet word, voordat 'n psalm betekenis vir die moderne gelowige kan kry nie. Dit is natuurlik geen groenlig om tekse fundamentalisties te interpreteer nie. 'n Deurgronde diakroniese analise van die teks kan in aanvulling tot literêre en teksimmanente ontleding, waarde tot 'n psalm se betekenis byvoeg. Die psalm se groei, Wirkungsgeschichte en interpretasie-geskiedenis blyk hier baie belangrik te wees. Psalms haal asem in die geskiedenis, maar moet in die hedendaagse konteks weer nuut interpreteer word. Eksegete kan daarom bevry wees van 'n enkelvoudige Sitz im Leben om die psalm te verstaan.

4 Psalm 55 en 74 kan as individuele en volksklaagliedere in 'n veelheid van omstandighede geaktualiseer en herinterpreteer word. Die veelheid van kontekste waarteen die psalms in die Ou-Testamentiese geskiedenis verstaan kan word, bevestig dit. Vir sowel die pastoraat en prediking as die geloofslewe van die enkeling of groep bied hierdie tekste hernude geloofsbelewenisse. Nie alleen bind hierdie tekste die huidige gelowiges aan 'n skare geloofsgenote se geloofservaringe uit die verlede nie, maar dit bring opnuut heling, krag en varsheid in gelowiges se eie geloofslewe met God. Opsigself is die herbelewenis van die psalms deur nasê, meditasie of sang, geloofsversterkend.

5 Oorwegend stimuleer hierdie analise die besef dat eksegete steeds moet worstel om die historiese en kultiese Sitze im Leben van psalms te bepaal, al weet hulle dat presiese ontstaansdatums en historiese kontekste nie bepaal kan word nie. Om 'n psalm of enige ander Ou-Testamentiese teks te verstaan, moet daar met die teks se agtergrondskontekste geworstel word. Sonder hierdie diakroniese diepgang, is 'n sinkroniese lees van tekste eensydig en onvolledig.

\section{NOTAS:}

1 F M Th Böhl, De Psalmen I en II (Tekst \& Uitleg), Groningen 1968, 94, meen dat die teks moeilik is omdat dit sinspelings op historiese gebeure bevat "die wij in bijzonderheden niet meer kunnen nagaan”. H J Kraus, Psalmen (BKAT XV/I), Neukirchen 1978, 405, sê: "Es wird sehr schwer sein, konkrete Vorgänge in Psalm 55 aufzudecken und zu erkennen”.

2 Die meeste eksegete identifiseer die stad (10b) met Jerusalem. B Duhm, Die Psalmen (KHAT/XIV), Tübingen 1899, 151, 153; F Baethgen, Die Psalmen 
(HAT), Göttingen 1904, 161; C A \& E G Briggs, A Critical and Exegetical Commentary on the book of Psalms (Vol I), Edinburgh 1907, 23; R Kittel, Die Psalmen abersetzt und erklärt (KAT), Leipzig 1929, 199; J Ridderbos, De Psalmen (COT), Kampen 1958, 113; A Deissler, Die Psalmen, Düsseldorf 1964, 219; A A Anderson, The Book of Psalms (NCB Vol I), London 1972, 415; J P M van der Ploeg, Psalmen. Deel I (BOT) Roermond 1973, 336; M Goulder, The Prayers of David (Psalm 51-72). Studies in the Psalter (JSOT Suppl 102), Sheffield 1990, 103; H Gunkel, Die Psalmen (GHAT II/2), Göttingen 1968, 238, vermeld 'n heidense stad terwyl M Dahood, Psalms II (AB), New York 1968, 30, dit met 'n Fenisiese stad identifiseer. Om 'n konkrete situasie in Psalm 55 te identifiseer, bly egter op 'n gemotiveerde vermoede gebaseer.

3 A F Kirkpatrick, The Book of Psalms, Cambridge 1921, 307, meen dat die skrywer nie bepaal kan word nie. M Treves, The Dates of the Psalms, Pisa 1988, 51, bevestig dit: "it is difficult to identify the author".

Verskeie navorsers onderskryf die moeilike datering van Psalm 55. Baethgen, $a$ w, 160: "wird es geratener sein, auf eine chronologische Fixirung (sic?) des Psalms zu verzichten". W O E Oesterley, The Psalms - Translated with textcritical and exegetical notes. Vol I (1-65), New York 1939, 284: "There is little to indicate a date". Dahood, $a w, 30$, meen dat daar geen kriterium vir datering is nie; Gunkel, $a w, 1968^{5}$, 239, sê: "Das genaue Zeitalter ist nicht festzustellen”. Anderson, $a$ w, 419, bevestig dit; J W Rogerson \& J W McKay, Psalms 51-100 (CBC), Cambridge 1977, 30: "The date of the writing cannot be determined". Ook M E Tate, Psalms 51-100 (WBC 20), Dallas 1990, 55, meen "date and identity... elude specific determination".

5 Hierby sluit onder andere Duhm, $a w, 151$; Kittel, $a w, 199$; Gunkel, $a w, 240$, en ander, aan.

Goulder, $a w, 97$, meen op grond van die vermelde motiverings "it is easy to see the situation as of an army which has been driven out of its city" en "the strength and bitterness of the psalm's feeling is an index of the military predicament". Hierdie standpunt word vroeër reeds deur $\mathrm{H}$ Birkeland, Die Feinde des Indviduums in der israelitischen Psalmenliteratur, Oslo 1933, 234; Evildoers in the book of Psalms, Uppsala 1955, 32, verteenwoordig, wat 'n buitelandse vyand identifiseer "in connection with war". Hy motiveer sy

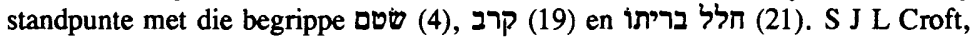
The Identity of the Individual in the Psalms, Sheffield 1987, 127, meen ook dat 'n koning se raadgewer hom verraai het deur 'n "military betrayal to a foreign power".

7 Die belangrikste literatuur en standpunte rondom die identiteit van die vyande in die Psalmboek word goed weergegee deur H Gunkel \& J Begrich, Einleitung in die Psalmen. Die Gattungen der religiösen Lyrik Israels, Göttingen 1933, 169 ev; Birkeland, $a w, 1933,1-19 ;$ N H Ridderbos, Die "Werkers der Ongerechtigheid" in die individuele Psalmen: Een beoordeling van Mowinckels opvatting, Kampen 1939, 2-18; G W Anderson, "Enemies and evildoers in the book of Psalms", BJRL 48/1 (1965), 18-29; O Keel, Feinde und Gottesleugner, Stuttgart 1969, 11-33; Kraus, a w, 1978, 112-117; H J Kraus, Die Psalmen (BKAT XV/III), Neukirchen 1979, 156-167; E S Gerstenberger, "Enemies and 
evildoers in the Psalms: A Challenge to Christian Preaching”, HBT 4/5 (1982/3), 61-77; Tate, $a$ w, 60-64 en P J Botha, Die teologiese funksie van die Torah-woordveld in die driehoeksverhouding Jahwe-vrome-vyand in Psalm 119, Pretoria 1992, 256-261. By 'n klaaglied van die enkeling is dit moeiliker om die vyand(e) te identifiseer as by klaagliedere van die volk. Die vernaamste standpunte word vervat in: "griechenfreundliche Parteigänger" as despotiese heersers (vgl Duhm, $a w$, xxev.); buitelandse politieke mag met die koning as spreker (vgl Birkeland, $a w, 1933,9,29$ ); Mede-Israeliete wat met leedvermaak siekte vererger/veroorsaak (vgl H Schmidt, Die Psalmen (HAT 15), Tübingen 1934, 132, 201; Gunkel, $a w, 1933,202$ ); towenaars wat met vervloekings of magiese woorde mense teister (vgl S Mowinckel, The Psalms in Israel's Worship II, New York 1962, 29); "mytische Mächte" (vgl Kraus, a w, 1979, 157).

8 Ridderbos, $a w, 1939,243$ en Ridderbos, $a w, 1958,110$.

9 F Delitzsch, Biblical Commentary on the Psalms, London 1889, 178; Ridderbos, a w, 1939, 243; H C Leupold, The Psalms, London 1959, 420; W S Scroggie, The Psalms (I-CL), London 1978, 31. Vir Goulder, a w, 8, 105, vorm nie net die opskrif nie, maar ook die Dawidsversameling (51-72) en volgorde van die psalms die interpretasiesleutel. So is psalms 51-72, volgens hom, Dawid se gebede wat in noue verband met die troonopvolgingsgebeure (2 Sam 15:7-17:29) staan. Die psalm is geskryf vir Dawid "in his lifetime by one of his closest attendants, a priest".

10 Böhl, $a w, 94$, meen die opskrif bring nie die psalm met Dawid se lewe in verband soos Psalms 52 en 54 nie. Ridderbos, $a w, 1958,111$, sê die psalm as geheel pas nie tydens Dawid se tyd nie.

11 Dit sluit die standpunte van onder andere Baethgen, $a w, 159$; Briggs \& Briggs, a w, 21; A F Kirkpatrick, The Book of Psalms, Cambridge 1921, 307 en Ridderbos, $a$ w, 1958, 111, in.

12 H Seidel, "Goulder, M: The Prayers of Dawid (Psalms 51-72)", TLZ 117/5 (1992), 349.

13 Birkeland, $a w, 1933,234$; J H Eaton, Psalms. Introduction and Commentary, London 1967, 147; J H Eaton, Kingship and Psalms. Studies in Biblical Theology 32, London 1976, 75.

14 Ridderbos, $a w, 1958,111$, verwys na 'n aantal ouer eksegete wat hierdie voorstel maak.

15 Eaton, $a w, 1967,147$, vermeld die moontlikheid en wys dit terselfdertyd as onseker af.

16 Vergelyk ooreenkomste met veral Habakuk 1:2 ev.

17 Kittel, a w, 199; A Weiser, The Psalms (OTL), London 1962, 420 en E J Kissane, The Book of Psalms, London 1966, 237. Kissane noem selfs die profeet Jesaja.

18 Baethgen, $a w, 159,162$; Briggs \& Briggs, $a w, 21$ en Kirkpatrick, $a w, 308$, lug almal hulle besware.

19 Briggs \& Briggs, $a w, 21$.

20 M Buttenwieser, The Psalms, Chicago 1938, 710-711.

21 Duhm, $a w, 152-153$.

22 Kittel, $a w, 199$. 
24 Weiser, $a w, 420$, meld die tye van Jeremia of die Makkabeërs, terwyl Böhl, $a$ $w$, 95, op drie moontlikhede wys: 'n datum rondom Dawid, die tydperk van 597-586 met konings Jojakim, Jojagin en Sedekia asook die Makkabeërtyd.

Gunkel, $a w, 1968^{5}$, 38, gee hierdie aanduiding oor verse $19 c-22$ en 24 nieteenstaande sy mening oor die psalm se datering: “Das genaue Zeitalter ist nicht festzustellen".

26 Vergelyk Kittel, $a w, 200$; Birkeland, $a w, 1933,234$; Ridderbos, $a w, 1939$, 243; Eaton, $a w, 1976,74$.

27 Duhm, $a w, 152$; Kraus, $a w, X V / 1,1978,403$.

28 Oesterley, $a w, 284$; Deissler, $a w, 219$; Van der Ploeg, $a w, 1973,335$ en Kraus, $a w, X V / I, 1978,403$, verteenwoordig almal 'n eksilies/ná-eksiliese datering op grond van taal- en stylkenmerke.

29 Die verbinding tussen "berit" en של word aangetref in Numeri 25:12 (Priesterskrif $+500-450 \mathrm{vC}$ ); Jesaja 54:10; Esegiël 34:25; 37:26 en Maleagi 2:5. "Berit" en חל kom slegs in Psalm 89:35 en Maleagi 2:10 voor. Al hierdie tekste kan met redelike sekerheid ná-eksilies gedateer word.

$30 \quad$ Baethgen, $a w, 162$.

31 Goulder, $a w, 24,97 \mathrm{ev}$.

32 D J Human, "A Tradition-historical analysis of Psalm 55", Skrif en Kerk 18/2 (1997), $272 \mathrm{ev}$.

33 Kraus, $a w, X V / I I, 1979,71$, meen “Psalmen lassen sich letzlich nur mit allergrößten Schwierigkeiten historisch fixieren und mit ihrer bewegten, hintergründigen Überlieferungsgeschichte festlegen".

34 A Gelston, "A note on Psalm LXXIV 8", VT 32 (1984), 83 en H Spieckermann, Heilsgegenwart - eine Theologie der Psalmen, Göttingen 1989, 126.

P Schelling, De Asafspsalmen, Kampen 1985, 224. Vir 'n latere (?) ontstaantyd noem hy ook raakpunte met Psalm 75 en die lied van Hanna in 1 Sam 2:1-10.

Schelling, $a w, 128$ en Spieckermann, $a w, 126$.

7 Vergelyk N A van Uchelen, Psalmen deel I:1-40 (POT), Nijkerk 1977, 225. Hy wys op:

- Sir Apok. Barug 29:4 - Die vyand se vlees is die voedsel vir die Israeliete wat in die Messiaanse tyd oorbly; of

- Targum Jerusalami - die vyand se vlees word gereed gehou tot op die dag van Israel se herstel;

- Baba Bathra 74 - In die toekomstige wêreld sal God die vleis van die Leviathan as maal vir die vromes gee; en

- 4 Esra 6:52.

Daar moet nietemin in gedagte gehou word dat die motief waar 'n seemonster/Leviatan as voedsel vir diere/voëls (Eseg 29:3-5; 32:2-4) of mense dien, nie in die Ou Testament goed ontwikkel is nie.

38 Hieronder tel Duhm, $a w, 196$ en Van Uchelen, $a w, 1977,249$.

39 Veral verse 4 en 8 dui op die vervolging van die Seleukiede weens die ooreenstemming van die woord מוֹצ. Vergelyk 1 Makk 1:39,45.

40 Schelling, $a w, 223$.

41 J J M Roberts, “Of signs, prophets and time limits. A note on Psalm 74:9", $C B Q 39 / 4$ (1977), 480. 
42 Schmidt, $a w, 142$. Vergelyk Daniel 1:8,31; 1 Makk 1:20ev en 2 Makk 5:11 ev.

43 Vergelyk Jesaja 14:8; Habakuk 2:17 en 'n inskripsie "Wadi Brisa". Waar ander eksegete die teks van vers 5 as "unintelligible" sien, meen R Sollamo, "The simile in Psalm 74:5. A woodcutter entering a forest wielding axes", SEA 54 (1989), 182, "it makes perfect sense" en is "skillfully composed". Verse 5 en 6 dui vir hom op Nebukadnesar se ontbostingsprogram aan die einde 7 de/begin 6de eeu.

44 Vergelyk Jeremia 46:22-3 ten opsigte van Egipte en Esegiël 31:12 ten opsigte van Assirië.

$45 \mathrm{~J}$ Jeremias, Das Konigtum Gottes in den Psalmen. Israels Begegnung mit dem kanaanäischen Mythos in den Jahwe-König Psalmen, Göttingen 1987, 29 en W Hermann, "Das Aufleben des Mythos unter den Judäern während des Babylonischen Zeitalters”, BN 40 (1987), 97, toon aan dat die gebruik van die mite onder die Judeërs in die Babiloniese tyd 'n oplewing getoon het. Dit bevestig dus ook 'n ná-eksiliese datering. T Veijola, Verheissung in der Krise. Studien zur Literatur und Theologie der Endzeit anhand des 89. Psalms, Helsinki 1982, 55, maak 'n opsomming van eksiliese Klageliteratur, waaronder hy die bovermelde psalms insluit.

46 Van der Ploeg, $a$ w, 1973, 448.

47 C Peterson, Mythos im Alten Testament. Bestimmung des Mythosbegriffs und Untersuchung der mythischen Elemente in den Psalmen, Berlin 1982, 150.

48 O Loretz, "Leberschau, Sündenbock Asasel in Ugarit und Israel”, UBL 3 (1985), 81, verdeel die psalm in drie tydperke, te wete 1) 1-2, 3-8, 9-11, 18-23 ...586/7; 2) 12-17 ...Deutero Jesaja; 3) 4 en 8 ...168.

W S Scroggie, The Psalms (I-CL), London 1978, 145, meen Psalm 74 "answer both to the Chaldean (586) and Antiochan (168) disasters". Ook volgens L Vosberg, Studien zum Reden vom Schöpfer in den Psalmen. Beiträge zur Evangelischen Theologie (Bd 69), München 1975, 22, ontstaan die psalm eers ná 586 (+587-538), maar hy deel $2 \mathrm{~b}, 3 \mathrm{a}, 4 \mathrm{~b}-6 \mathrm{a}$ en $12-14$ as glosse aan die Makkabeërtyd toe.

$50 \quad$ Vergelyk Loretz, $a w, 81$ en Sollamo, $a w, 183$.

51 Deissler, $a w, 286$ en K J Illmann, Thema und Tradition in den Asaf-Psalmen, ABO 1976, 28.

52 Kirkpatrick, $a w, 442$.

53 Böhl, $a w, 132$.

54 Oesterley, $a w, 346$.

55 Ridderbos, $a w, 1958,252$.

56 Vergelyk Buttenweiser, $a w, 609$, se vermelding van hierdie standpunt op grond van 1 Makk 4:38 en 2 Makk 1:8 en 8:38.

$57 \quad$ Weiser, $a w, 518$.

$58 \quad$ Kraus, $a w, \mathrm{XV} / \mathrm{II}, 1978,679$.

59 K Seybold, Die Psalmen. Eine Einführung, Stuttgart 1991, 52-54, 89. 